\title{
Exploring the Magnesium-deficient Weanling Rat as an Animal Model for the Sudden Infant Death Syndrome: Physical, Biochemical, Electrocardiographic, and Gross Pathologic Changes
}

\author{
JOAN L. CADDELL \\ Department of Pediatrics, St. Louis University School of Medicine, St. Louis, Missouri, USA
}

\section{Summary}

An hypothesis has been proposed that a relative or absolute deficiency of magnesium in the rapidly growing infant might be a major cause of the sudden infant death syndrome (SIDS, crib death). We studied the magnesium-deficient weanling rat as an animal model for the human infant, exploring physical, biochemical, and gross pathologic changes during the sudden seizure episode of magnesium deficiency, as compared with during fatal strychine seizures. In addition, the electrocardiographic changes were examined during this episode of magnesium deficiency.

No audiogenic seizures could be elicited on day 7 in any of five rats with acute magnesium deficiency $(0-\mathrm{Mg})$ that fasted for $24 \mathrm{hr}$. The plasma magnesium concentration of 0 -Mg rats with no known seizures was $0.36 \pm 0.02(27)$; the plasma magnesium value increased during fasting to $0.96 \pm 0.06(P<0.001)$.

Apparently new findings in the blood chemistries associated with the seizure-shock episode of magnesium deficiency inclutle a sharp increase in plasma osmolality, hematocrit, blood sugar, blood urea nitrogen, uric acid, and the activity of SGOT, SGPT, LDH, and creatine kinase.

Electrocardiograms were taken in rats that weighed 28-32 $\mathrm{g}$ at the onset of the study. During the seizure-shock episode, there was sinus arrest, and the ventricular rate precipitously dropped to about one-third of the normal rate. The ventricular complexes were sometimes initiated from two electrical foci. Apnea persisted and bradycardia was rapidly progressive in rats that died. Other rats made rapid, spontaneous recoveries; the heart rate and rhythm improving as animals resumed respirations. Spiked electrical complexes sometimes developed during the early recovery period. The tracings normalized within $18 \mathrm{hr}$.
Pronounced intrathoracic pathologic changes were found in rats after a fatal tetanic and apneic episode. In these animals there was some variation in the severity of pathologic change. The most severe pathology was usually found in the smallest and youngest animals and usually included scattered petechiae on the pleura, the thymus, and the pericardium; expanded lungs that were plumcolored in areas extending from the hilus and in scattered patches throughout; edema and congestion on the cut surface; and foamy fluid, sometimes blood-tinged, in the bronchi. The right atrium and the right ventricle were usually distended with dark, fluid blood. The urinary bladder was always contracted and empty.

When weighed with fluid contents, both the heart and lungs of the $0-\mathrm{Mg}$ rats that died of seizures weighed more than those of 0 $\mathrm{Mg}$ rats with no known seizures. The weights in grams of four rats from each of these two groups were, respectively: body weights, $53.9 \pm 0.05$ and $53.8 \pm 0.08$; lungs, $0.831 \pm 0.038$ and $0.585 \pm 0.05$ $(P<0.001)$; and hearts, $0.636 \pm 0.042$ and $0.40 \pm 0.03(P<0.005)$. In contrast to rats dying of magnesium deficiency, rats that died of seizures due to strychnine were only mildly cyanotic. Their lungs were only slightly inflamed, with occasional petechiae. Their body weights and the weights of their lungs and hearts were not significantly different than the weights of four controls.

\section{Speculation}

The sudden, potentially fatal episode occurring in the very young magnesium-deficient rat and in SIDS victims appears to be a form of shock similar to anaphylactic shock, but without a sensitizing agent. Pathologic changes are not due to the violence of seizures alone, but could well be caused by biochemical events associated with the shock state. 


\section{INTRODUCTION}

Sudden unexpected death in human infants (SIDS, crib death) is the larges single cause of postneonatal infant mortality (3). It has an incidence of 2 to 3 per 1000 live births (8), and involves approximately one-third of all babies dying after the first week and before the end of the first year of life in the United States (64). The cause remains unknown, al though much new information concerning SIDS has been learned through recent research, as summarized in Hasseimeyer's report from the National Institute of Child Health and Human Development (47). A hypothesis (19) has been proposed that a relative or absolute deficiency of magnesium (possibly with an associated mineral imbalance) (29) in the rapidly growing infant might be a major cause of SIDS.

Magnesium deficiency is a relatively important problem in the human infant $(24,63,71,73,85)$. In one series from Edinburgh, Scotland (14), of the 12 per 1000 neonates with convulsions, about 7 per 1000 were due to primary uncompl icated hypocalcemia/hypomagnesemia. Magnesium deficiency has been diagand in infants and young children who had metabolic and nutritional disorder to thrive, apathy nonspecific findings including hyperirritability, failure to thrive, apathy, anorexia, sudden onset of apnea or respiratory distress,
and tonic and clonic seizures $(7,16,21,26,28,45,63,71,73)$. Because magnesium deficiency occurs in conjunction with other medical problems, it is magnesium deficiency occurs in conjunction with other medical problems, it is
best to investigate the syndrome through study of animal models without complicating illness.

Magnesium deficiency causes sudden, unexpected death in animals. There are species differences and intraspecies variations. Young cows sometimes mice died almost $(20,49,62)$ and dogs (62) usually developed vasodilatation, hyperirritability, and a , 62) and dogs (62) usually developed vasodilatation, hyperirritability, death. The lower the weight and age of the animal at the onset of magnesium deprivation, the shorter the life and the more abrupt the death $(49,62)$. Early death may follow a period of rapid growth, particularly if the diet is $1 \mathrm{im}-$ ted in magnesium but rich in protein, calcium, and phosphorus, three nutrients that increase the metabolic requirement for magnesium, as previously reviewed $(15,24)$. One would expect the period of most rapid growth in early infancy to be the most vuinerable age in man (19).

It is not known whether magnesium deficiency may provoke a sudden, fatal episode in the human infant, but because of its potential importance, we have studied this event in detail in the magnesium deficient weanling rat as an an-
imal model for the human infant. We explored physical, biochemical, and gross pathological changes related to the sudden seizure episode of magnesium deficiency, as compared to these after fatal strychnine seizures. The electrocar diographic changes were studied during this episode of magnesium deficiency. Data from magnesium deficient weanling rats were compared with reported findings in various types of shock and in human infants dying from SIDS. Finally,
we have reviewed studies that have tested the hypothesis directly and indirectwe have reviewed studies that have tested the hypothesis directi
ly, in the light of findings from recent SIDS research (47).

\section{MATERIALS AND METHODS}

\section{Animals}

Male weanling Sprague-Dawley rats weighing $28-40 \mathrm{~g}$ (Hilltop Lab Animals, scottdale, $\mathrm{Pa}$.) were individually housed in raised bottom stainiess steel cages and provided with deionized water ad libitum. Unless otherwise stated, they were fed ad libitum and were in the fed state when studied. All rats were itored.

\section{Animal Diets}

To achieve acute magnesium deficiency that often resulted in spontaneous seizures and death at one week (a model for SIDS infants that died before six months of age), weanling rats were fed a diet that provided only $0.3 \mathrm{mg}$ of magnesium/ $100 \mathrm{~g}$ of diet and no added magnesium $(0-\mathrm{Mg}), 20 \%$ casein, and other nutrients 1 isted in Table 1 . Their controls were fed the same diet, but with $100 \mathrm{mg}$ of magnesium/ $100 \mathrm{~g}(100 \mathrm{Mg})$.

To achieve attenuated magnesium deficiency that of ten resulted in spontanous seizures and death at two weeks (a model for SIDS infants that died during the second six months of life), weanling rats were fed a diet that provid$5 \mathrm{mg}$ of added magnesium $(5-\mathrm{Mg}), 40 \%$ casein, and other nutrients listed in Table 1 . Their controls were fed the same diet, but with $150 \mathrm{mg}$ of magnesium/
$100 \mathrm{~g}(150-\mathrm{Mg})$, the higher magnesium to accomodate the higher protein, calcium, $100 \mathrm{~g}(150-\mathrm{Mg})$, the higher magnesium to accom.da
and phosphorus in the additional case in (27).

Natural controls were fed laboratory chow (LC) (No. 5001, Ralston Purina Co., St. Louis, Mo.) for one or two weeks. This contained $23.4 \%$ crude vege-
table protein and $210 \mathrm{mg}$ of magnesium/ $100 \mathrm{~g}$.

\section{STUDY DESIGNS AND PROCEDURES}

A rat was studied once for one procedure (blood sampling, pathology, etc.) at one point in the experiment (during seizures, $\frac{1}{2} \mathrm{hr}$ post seizures, etc.) and was then destroyed. There was one exception: the same rats in the electroca diograph study were photographed at autopsy. There were 6 to 14 samples in raised for study. Some died and could not be studied. Hemolyzed samples wer discarded. Rarely, plasma from two similar animals was combined as one sample. eously; 60 rats were raised for study at one time; controlled studies were run serialiy in close sequence. The combined purified controls were therefore the largest groups.

Baseline studies were made on day 6 in acutely deficient $0-M g$ animals with no knowm previous seizures (Fig. 1), and on day 13 the $5 \mathrm{Mg}$ rats with attenuated magnesium deficiency. One day after basel ine studies, similar rats were individually subjected to an auditory stimulus, ringing metal keys that had a sound pressure level of 80 decibels, concentrated between 4 and $32 \mathrm{kilohertz}$. The keys were rung unti] the rats convulsed, but not in excess of $60 \mathrm{~seconds}$.
A group of five $0-M g$ rats with no known seizures were fasted for $24 \mathrm{~h}$ between days 6 and 7 and challenged with auditory stimuli.

There were three separate investigations concerning blood chemistries that included whole venous blood hematocrit, plasma magnesium, and a clinical
chemical profile performed on an autoanalyzer.
1. Comparisons during seizures in acute magnesium deficiency with those due to strychnine.

$100-M g$ controls were fed ad libitum or pair-fed with $0-M g$ rats. Some pair-fed 100-Mg rats were studied as controls, and some were treated with strychnine in the dose of $1.9 \mathrm{mg} / \mathrm{kg}$ of body weight intraperitoneally, a dose found to produce fatal seizures that clinically best simulated those of acute magnes ium deficiency. The strychnine-treated rats were studied at the end of sever seizures, at the point of death. Groups of $0-\mathrm{Mg}$ rats with acute magnesium de-
ficiency were studied in the preseizure period on day 6 , and on day 7 at the ficiency were studied in the preseizure period on day 6 , and
onset of seizures and immediately after prolonged seizures.

\section{Further studies during the seizure episode in acute magnesium deficiency.}

Baseline studies were made in $0-M g$ rats with no known seizures and in $100-$ $\mathrm{Mg}$ and $\mathrm{LC}$ controls on day 6 , Other $0-\mathrm{Mg}$ rats were studied on day 7 during seizures, or during the recovery period, $18 \mathrm{~h}$ after seizures.

Additional chemical studies were made in $0-\mathrm{Mg}$ and $100-\mathrm{Mg}$ rats raised in close was found by freezing point determination of lithium-heparinized plasma on an osmometer (Fiske Assoc., Uxbridge, Mass.), and plasma specific gravity was tested in plasma and urine using Ketoztix (Ames Co., Elkert, Ind.); the urine was obtained from the urinary bladder under direct visualization using a tuber was obtained from the urinary bladder under direct visualization using a tube
cul in syringe. Plasma lactic acid was measured on a Calbiometer (Calbiochem Co., La Jolla, Cal.); and $\mathrm{pCO}_{2}$, on a pH blood gas analyzer (Model 213 , Instrur mentation Lab., Inc., Lexington, Mass.). When available, blood from the animals raised for these additional chemical studies was sometimes analyzed for
whole venous blood pH, hematocrit, or plasma magnesium at appropriate intervals between days 6 and 8 .

3. Studies during the seizure episode in attenuated magnesium deficiency.

Basel ine studies were made on 5 -Mg rats with no knowm seizures and in $150-\mathrm{Mg}$ and LC controls on day 13 . Other $5-\mathrm{Mg}$ rats were studied on day 14 post repeated seizures or after death, or on day $15,18 \mathrm{~h}$ after seizures.

Animals were anesthetized with sodium pentobarbital (Abbott, N. Chicago, 111.) in an intraperitoneal dose of $5 \mathrm{mg} / 100 \mathrm{~g}$ of body weight for all painful procedures, and at the end of such procedures they were killed with an overdose
of this drug. About $1 \mathrm{ml}$ of blood was drawn percutaneously from the right venof this drug. About $1 \mathrm{ml}$ of blood was drawn percutaneously from the right ven-
tricle in plastic syringes that had been prepared with lithium heparin (Sigma, St. Louis, Mo.). Whole blood $\mathrm{pH}$ readings were made on a digital pH meter (Model 3550 , Beckman Instruments, Irvine, Cal.). Duplicate microhematocrit determinations were made using a microhematocrit centrifuge (Damon/IEC Divisions, Heedham Hts., Mass.), and read manually. The blood was centrifuged at $3^{\circ}$ (Damon (ECIPRU), and the plasma was separated and stored at $3^{\circ}$ until analyzed with in $24 \mathrm{~h}$. Duplicate plasma samples were diluted 1:50 in $0.1 \%$ lanthanum solu303 , Perkin-Elmer Corp., Norwalk, Conn.). The chemical profile was made on the SuAC $\mathrm{ml}$ of plasma was required. The mean coefficient of variation for the SMAC system was 3.2 ( 81$)$.

\section{Electrocardiograms.}

Electrocardiograms were taken on a model VS4 Cambridge instrument (Ossining, N.Y.) on unconscious or sedated animals, using needle electrodes inserted in the dorsum of the feet of supine animals. This study was limited to rats that weighed $28-32 \mathrm{~g}$ on day 0 of the experiment. On day 6 , electrocardiograms were taken in five $100-\mathrm{Mg}$ controls and five $0-\mathrm{Mg}$ rats that had not convulsed. On day 7 , five $0-M g$ rats that becane
were studied without any sedation.

\section{Gross pathological examinations.}

Gross pathological examinations were conducted immediately after death. No blood samples were taken; the intact hearts and intact lungs were weighed No blood samples were taken; the intact hearts and intact lungs were weighed
on a mode1 H 20 Mettler balance without disturbing their fluid contents.

\section{Statistical analyses.}

Statistical analyses were made using standard tables for two-tailed Student's $t$ distribution or the analysis of variance. The statistics throughout ber of samples in brackets, and the probability.

\section{RESULTS}

GROWTH AND PHYSICAL BEHAVIOR

Controls.

Analysis of variance testing showed no difference in the increment of weight gain between days 13 and 14 in the three groups of 10 control rats that were studied for growth; their initial weights approximately doubled at one week and tripled at two weeks. All controls remained calm throughout the study taneously.

Acute magnesium deficiency.

For the first three days, the $0-M g$ rats in this study grew as we 11 as the controls, but they then became anorexic and between days 3 and 4 their weight gain was reduced $(P<0,05)$. They began to develop hyperemia, which was fading by day 6 . Between days 6 and 7, the difference in weight gain between the control and acute groups was highly significant $(P<0.001)$, and the animals were tremorous, hyperirritable, with exaggerated startle reactions. On day 7 , rats that initially weighed $35-40 \mathrm{~g}$ usually developed apnea and tonic seizures. (Rats that did not convulse on day 7 of ten had physical changes suggesting recent seizures, and they were not studied). Rats that survived the seizure episode began to breathe spontaneously and began to exhibit variable activity that included hyperventilation, clonic seizures, or lassitude, followed by a return
to normal activity. They usually resisted further audiogenic seizures for at to normal activ

No audiogenic seizures could be elicited on day 7 in any of the $0-M g$ rats that had fasted for $24 \mathrm{~h}$. 


\section{Attenuated magnesium deficiency.}

Between days 2 and 3 , the $5-\mathrm{Mg}$ rats showed significantly less weight gain than those fed $150-\mathrm{Mg}$ control diet, $(\mathrm{P}<0.05)$, a trend that persisted throughout this study. Erythema usually developed by day 7 and faded by day 12, when auditory stimuli on day 14 , these rats usually had violent and prolengith vulsions and and often with bloody froth a imals recovered more slowly than surviving 0-1tg rats with acuted surviving anficiency.

\section{CHEMICAL CHANGES IN THE BLOOD.}

\section{$\frac{\text { Experiment 1.: } \text { Comparisons during seizures in acute magnesium deficiency with }}{\text { those due to strychnine. }}$}

Examination of the clinical chemical profile (Tables 2 A,B,C) showed some differences between $100-\mathrm{Mg}$ controls fed ad libitum and those pair-fed. The expected findings due to magnesium deficiency, reduced plasma protein and reduced activity of alkal ine phosphatase (EC 3.1.3.1.) were found. During the seizure-shock episode, the blood pH rapidly decreased, while highly significand increases $(P<0.001)$ were found in blood hematocrit, plasma magnesium, calcium, potassium, inorganic phosphorus, uric acid, iron, total protein, total bilirubin, and the plasma activity of Glutamic-oxaloacetic transaminase (SGOT) (EC 2.6.1.1.), Lactate dehydrogenase (LDH) (EC 1.1.1.27), and ATP:creatine Nphosphotransferase (Creatine kinase) (EC 2.7.3.2.), and a smaller increase
(P< 0.01) was found in plasma activity of Glutamic-pyruvic transaminase (SGPT) $(P<0.01)$ was four
$(E C$ 2.6.1.2.).

Greater changes were found in blood measurements such as the hematocrit and the plasma enzyme activity in the convulsing $0-M g$ rats compared with pair fed rats dying of strychnine seizures $(P<0.001)$. The mean $\mathrm{pH}$ value of five 0 -Mg rats that died of seizures, $6.94 \pm 0.01$, was significantly different from that of four rats that died of strychnine seizures, $7.09 \pm 0.01 \quad(P<0.05)$.

\section{Experiment 2.: Further studies during the seizure episode in acute magnesium}

Blood chemistries were studied before, during, and $\frac{1}{2} h$ after a single sejzure episode. During the seizure episode, the whole venous blood $\mathrm{pH}$ decrease Fig. 3 and 4 ), returning to preseizure levels during values sharply increase

The SMAC clinical chemical profile was conducted in the following groups of rats; the numbers in brackets indicate the final number of samples analyze purified controls (100-Mg) (22), laboratory chow-fed controls (4) and at the following times in magnesium deficient $0-20$ rats: on day 6 in animals with no known seizures $(9)$, during a single seizure episode $(20), \frac{1}{2} \mathrm{~h}$ after a seizure episode $(5)$, and $18 \mathrm{~h}$ post seizures $(6)$. The same plasma constituents reported in Table 2 were studied. No significant differences were found in the blood chemistries of the $100-\mathrm{Mg}$ and the laboratory chow controls. The values of the $100-\mathrm{Mg}$ controls and the pattern of change in the $0-\mathrm{Mg}$ rats during seizures in this study were essentially the same as corresponding data in Experiment 1 ( $T$ a-

One noteworthy change was seen $\frac{1}{2} h$ after a single seizure episode: the mean plasma glucose value increased from the preseizure level of $148.4 \pm 7.6$
to $795.2 \pm 11.8 \mathrm{mg} / \mathrm{dl} \quad(P<0.01)$. Within $18 \mathrm{~h}$ of a single seizure episode, all blood chemistries had return-
ed to preseizure levels.

Additionat studies in acute magnesium deficiency on days 6 and 7.

Plasma osmolality. No difference was found in the plasma osmolality of $100-\mathrm{Mg}$ controls, $306.0+1.54(4)$ and $0-\mathrm{Mg}$ rats with no known seizures 306.6 +2.07 (4) $\mp 3.6$ (4) $\quad(P<0.001)$, and it further increased after prolonged seizures to 353.2

The mean osmolality of five $0-\mathrm{Mg}$ rats that fasted for $24 \mathrm{~h}, 319.8 \pm 2.26$, was greater than that
$0-M g$ rats $(P<0.01)$

Plasma specific gravity. The mean plasma specific gravity for two $100-\mathrm{Mg}$ co known seizures, 03 at the onset of two 0 -Mg rats were 1.027 in rats with zures, and greater than 1.035 after fatal seizures. These dat follow seitrend of the plasma osmolality.

Plasma lactic acid. Plasma lactic acid, determined in three rats in each group, was, in $\mathrm{mg} / \mathrm{dl}: 49.3+12.2$ in sedated $100 \mathrm{Mg}$ controls, $60.7 \pm 6.3$ in tremorous $0-\mathrm{Mg}$ rats, and $117 \overline{7} .2^{\circ}+13.1$ in rats with severe convulsions.

Right ventricular $\mathrm{pCO}_{2}$. The right ventricular blood $\mathrm{pCO}_{2}$ of $100 \mathrm{Mg}$ con trols was $41.75 \pm 1.01(4)$ and for hyperirritable $0-\mathrm{Mg}$ rats was $37.0 \pm 2.16$ (3). Following prolonged apnea and tonic-clonic seizures, the value in $0-M g$
rats was $58.1+3.29(4)$.

Plasma and urinary ketones. No acetoacetic acid was found in plasma or in available samples of urine except for urine from five fasted $0-M g$ rats, which
was a mean value of 1.2 on a 0 to $4+$ scale. No urine was found in the bladder of rats that had had a seizure episode.

\section{$\frac{\text { Experiment 3.: }}{\text { deficiency. }}$}

Blood chemistries were studied before, during, $18 \mathrm{~h}$ after seizures, and at death. iency showed a pattern of change similar to that of 0 -Mg rats with acute magusually returned to the preseizure level within $18 \mathrm{~h}$ post seizures.

The venous blood $\mathrm{pH}$ of $150-\mathrm{Mg}$ controls and $100-\mathrm{Mg}$ controls was the same, and the $5-\mathrm{Mg}$ rats closely followed the pattern of the $0-\mathrm{Mg}$ rats shown in Fig nificantly higher than that of the $100-\mathrm{Mg}$ rats (Fig. 3)(P<0.00i). The preseizure $5-\mathrm{Mg}$ animals had a mean hematocrit of $38.7 \pm 0.63(13)$, which increased
to $44.6 \pm 1.21(5)$ after seizures $(P<0.001)$, and to $49.4+2.16(5)$ in rats that died $(P<0.001)$. The mean plasma magnesium value of $5-\mathrm{Mg}$ rats followed the pattern of change show in the $0-M g$ rats in Fig. 4. Prior to known seizures,
the value was, in mEq/ liter, $0.43+0.02(10)$, which increased to $1.39+0.12$ (6) post repeated seizures $(P<0.001)$, and returned to the preseizure Tevele

$0.40+0.02(10) 18 \mathrm{~h}$ after seizures.

The SMAC clinical chemical profile was conducted in $150-\mathrm{Mg}$ controls (12), laboratory chow-fed controls (11), post repeated seizures (7), at the point of death (7), and $18 \mathrm{~h}$ post seizures (7). The $150-\mathrm{Mg}$ control plasma protein were $(P<0.001)$ Highest values for blood urea nitroge were found after seizures in moribund $5-\mathrm{Mg}$ animals, $36.75+1.43 \mathrm{mg} / \mathrm{dl}$ (7), which was significantly higher than the $5-M g$ preseizure value, $30.41+0.67 \mathrm{mg} / \mathrm{dl}(12)$ ( $P<0.001)$. Similarly, the uric acid values at the point of death were $3.50+1.50 \mathrm{mg} / \mathrm{dl}(7)$, increased compared to preseizure values, $1.82+0.26 \mathrm{mg} / \mathrm{dl}(\overline{12})(P<0.001)$. As in the first two experiments, nearly ali of the blood components tested, including the plasma enzyme activity, increased significantly during seizures, but then quickly returned to preseizure levels; only three plasma values were still significantly elevated above the preseizure level $18 \mathrm{~h}$ post seizures: calcium
$(P<0.025)$; protein, $(P<0.05)$, and urea nitrogen, $(P<0.05)$.

\section{ELECTROCARDIOGRAPHIC CHANGES}

Changes in the electrocardiograms are shown in Fig. 5, and are described in the legend.

\section{GROSS PATHOLOGICAL CHANGES}

Findings after fatal seizures due to magnesium deficiency.

External features. Control rats fed the purified diets and those fed laboratory chow were indistinguishable. Rats dying of acute magnesium deficiency appeared to be well hydrated and in good physical condition, al though their
body weights were lower than the mean weights of magnesium-fed controls. Rats dying of attenuated magnesium deficiency had coarser and thinner coats and dying of attenuated magnesium deficiency had coarser and thinner coats and
weighed less than controls, but they appeared to be well hydrated and adequate ly nourished.

Rats that died quickly in apnea and tetany rarely showed more than mild cyanosis. Those dying after prolonged seizures, whether from acute or atten uated magnesium deficiency, were deeply cyanotic, and they of ten had froth in sometimes securing a wire of the cage in their mouths. Their forepaws were
sing tightly flexed.

Internal features. The 100-Mg controls had light salmon-colored lungs that filled about two-thirds of the thoracic cavity. There were no areas of inflammation and no petechiae (Fig. 6). About $0.5 \mathrm{ml}$ of urine could usually be ob-

The lungs of 0 -Mg rats that had had no known seizures were slightly in-

flamed, and their hearts were not remarkable.

The internal pathological changes were chiefly intrathoracic in magnesium deficient rats that died spontaneously after a sudden apneic and tetanic episode. The animals represented in Fig. 6 weighed $28-32 \mathrm{~g}$ initially, and they were shipped in December, 1977, a cold month. In these 0-Mg rats, scattered petechiae were usually found on the pleura, the thymus, and the pericardium. The lungs were fully expanded and did not collapse with time; plum-colored
areas extended from the hilus and in scattered patches throughout. areas extended from the hilus and in scattered patches throughout. Edema an congestion were seen on the cut surface, and foamy fluid, sometimes blood-
tinged, was found in the bronchi. The right atrium and the right ventricle tinged, was found in the bronchi. The right atrium and the right ventricle
were of ten distended with dark, fluid blood. The livers were darker than those of the $100-\mathrm{Mg}$ controls. The urinary bladders were contracted and empty. These features describe al1 magnesium deficient weanling rats dying spontaneously throughout this study, with some variation in the number and distribution of petechiae, lung expansion, severity of hemorrhage, and other pathological find-
ings. The most severe changes were usually found in the smallest and youngest ings. The
animals.

Both the hearts and lungs of the 0-Mg rats that died of seizures weighed more than those of $0-M g$ rats with no known seizures. The weights in grams of
four rats from each of these two groups were, respectively: body weights, 53.9
+0.5 and $53.8+0.8$; lungs, $0.831+0.038$ and $0.585+0.05$ (P 0 . +0.5 and $53.8 \pm 0.8$; lungs, $0.831 \pm 0.038$ and 0.58
hearts, $0.636 \pm 0.042$ and $0.40 \pm 0 . \overline{0} 3(P<0.005)$

\section{Findings after fatal seizures due to strychnine poisoning}

The $100-\mathrm{Mg}$ rats that died of seizures due to strychnine poisoning were mildly cyanotic, and their bodies and hind legs were in rigid extension. Their petechiae on the pleurae. Their body weights and the weights of their lungs and hearts were not significantiy different from the weights of their lungs controls. These respective weights in grams were: body weights, $67.0+2.8$ and $72.8 \pm 2.5$; lungs, $0.68 \pm 0.02$ and $0.69 \pm 0.02$; and hearts, $0.47 \pm 0.02$
and $0.50 \pm 0.07$.

\section{DISCUSSION}

\section{PART I. TESTING THE HYPOTHESIS IN AN ANIMAL MODEL (THE PRESENT STUDY)}

The present study examined the sudden, potentially fatal seizure episode in the magnesium deficiency syndrome in weanling rats serving as models for the human infant of several months to one year of age. The model for the infant during the first six months of life was studied in more detail, because the greatest number of SIDS deaths occur before six months of age (87), with a peak incidence between two and four months $(8,87)$. Since the newborn rat has many characteristics of the premature human infant (37), an early-weaned rat is an approximate model for the full term human infant. If three years in the life of a rat is approxinately equal to 90 years of human life (37), six rat-days would correspond to about six months of human life. The rate of growth in the control rats is similar to that of the full term human infant
that usually doubles his birth weight in five months and triples it in one that usually doubles his birth weight in five months and triples it in one
year (89).

An attenuated magnesium deficiency (27) was produced by feeding an amount of magnesium known to support life under normal dietary conditions (20), commagnesium and aggravates the magnesium deficiency syndrome $(15,20,57)$. The 
higher protein and non-protein nitrogen products in the blood of animals fed thesium, young rats, particularly those deficient in mag

COMPARISON OF CHANGES FOLLOWING FATAL SEIZURES DUE TO ACUTE MAGNESIUM DEFICIENCY WITH THOSE DUE TO STRYCHNINE

The data in Experiment 1 showed that the biochemical changes in $0-M g$ rats that survived seizures were more severe than the changes after fatal strychnine seizures. The magnesium deficient rats had evidence of greater hemoconcentration than the strychnine-treated rats, and only the magnesium deficient animals had evidence of significant increases of fluid in the lungs. The increase in activity of SGOT, SGPT, LDH, and creatine kinase following the seizure episode of magnesium deficiency was greater than the increase that followed fatal strychnine seizures. This suggests a greater increase in membrane permeability in the magnesium deficient animals at that time. Kulka (50) reported temporary plasma leakage from dilated vessels in the ears of magnesium deficient weanting rats.

\section{COMPARISON OF REPORTED FINDINGS IN SHOCK WITH THOSE OF THE
SEIZURE-SHOCK EPISODE OF MAGNESIUM DEFICIENCY}

Physical findings. The classic symptom complex common to all forms of shock may include apathy, pallor, hypothermia, hypotonia, and tremors (92). Particularly in anaphylactic shock, the onset may be sudden and unexpected, and
the condition may be rapidly fatal $(6,93)$, or self limiting (93), followed by the condition may be rapidly fatal
rapid and complete recovery (33).

The rats in the present study appeared to be in shock during the seizure episode. The unpredictability of their courses, ranging from precipitous death hylactic shock.

Electrocardiographic changes. Variable changes in rate, rhythm, and the ported in anaphylactic shock $(11,13,43)$, with reversal to the preshock patported in anaphylactic shock $(1,13,43)$.
tern within $3 \frac{1}{2}$ hours in one patient $(13)$.

The electrocardiographic changes in $0-\mathrm{Mg}$ rats in the present experiment were nonspecific. They also involved changes in rate, rhythm, and what appeared to be the ST-T complexes, and rapidly normalized in recovering animals.

Chemical changes in the blood. Many conditions such as hemorrhage, trauma, and anaphylaxis can cause a shock state $(10,75)$ which initiates a chain of biochemical events that tends to maintain the shock (10). This may include involvement of neurohumoral transmitters and vasoactive substances, and possibiy various proteases, lysosomal enzymes, and kinins (10). In anaphylaxis, the clinical manifestations are entirely due to the action of diverse chemical mediators that are rapidly released. Histamine, slow reacting substance of meability, contract smooth muscle, and attract inflammatory cells $(6)$.

Changes in the blood chemistries common to all forms of shock may include the following, with modifications depending on the form of shock: decreased $\mathrm{pH}$; increased hematocrit; increased plasma potassium, calcium, magnesium, and
phosphorus; an early rise and subsequent decline in plasma glucose; elevation phosphorus; an early rise and subsequent decline in plasma glucose; elevation
of plasma non-protein nitrogen components; and increased activity of several of plasma non-protein nitrogen components; and increased acti
enzymes in plasma, including SGOT, SGPT, and LDH $(44,59,75)$.

During and immediately after the seizure episode, the rats in the present study had chemical changes in the blood similar to those of shock. Terminal findings included elevation of both plasma $\mathrm{pCO}_{2}$ and plasma lactate, associated with a decreased blood $\mathrm{pH}$. As Moore pointed out (59), this combination of superimposed respiratory acidosis upon the already mounting lactic acidosis of superimposed respiratory acidosis upon the already mounting lactic acidosis of the low flow state of shock. The rats were apparently
zure episode which might weil be called seizure-shock.

Pathological changes. In anaphylactic shock as it occurs in man (51) and cattle (3), findings include frothy fluids in the bronchi and in mally inflated lungs that fill both pleural cavities. These lungs weigh more than usua and show areas of pink emphysema and plum-colored atelectasis and scattered atation (51), and the urinary bladder is usually empty (33).

The pathological changes of animals dying suddenty of magnesium deficiency closely resembled the above description. As noted above, these findings were not seen in rats dying of strychnine seizures, although tetany, apnea, and sometimes clonic seizure activity was common to both syndromes. The cause of death in strychnine poisoning is generally considered to be hypoxia (36). The pathological changes of magnesium deficiency were not due to the physical activity during seizures, but could have been rela
initiated during the seizure-shock episode.

COMPARISON OF REPORTED FINDINGS IN SIDS WITH THE SEIZURE-SHOCK EPISODE OF MAGNESIUM DEFICIENCY

Neonatal features and growth. Prospective studies have shown that the SIDS infant was often born prematurely $(8,40)$, or was underweight for gestational age (61), had lower Apgar scores (61), was in greater perinatal disthroughout the first six months $(65)$, or just before death $(61)$.

Unlike the SIDS babies, the rats in the present study were normal until fed the magnesium-restricted diets. The acutely deficient rats had impaired growth terminally, and rats with attenuated magnesium deficiency had suboptimgrowth terminally, and rats with attenuated magnesium deficiency had suboptimal growth throughout the study. Thus both types of growth retardation found in
SIDS $(61,65)$ were represented. A better model for SIDS might have been pups SIDS $(61,65)$ were represented. A better model for SIDS might have been pups
born to magnesium deficient dams; in this situation the dams look well, but the pups may be stillborn (90), of low birth weight $(34,90)$, and have high perinatal morbidity $(34,90)$ and mortality $(90)$.

Physical and electrocardiographic changes during apparent life-threatening episodes. Severe, apparently life-threatening episodes suggested to death syndrome. Harris $(46)$ described an infant who had syncopal epi sodes of sudden onset during which the electrocardiogram revealed ventricular rates of 30 to $40 /$ min., but was normal between attacks. The infant died suddenly during such an episode; petechiae, presumably intrathoracic, were found on postvious fainting, cyanotic or apneic episodes, or periodic breathing. Stein-
vich schneider (78) studied five infants who developed apnea and cyanotic episodes of undetermined origin; two died of SIDS. In one baby he studied, the bradycardia improved when the cardiac electrical activity was initiated from an ectopic focus (77). Stevens (79) traced the progression in four infants from the sudden onset of apnea, pallor, and bradycardia to labored and deep inspiratory sponsiveness to an auditory stimulus, Salk et al. (72) noted that the future SIDS victim showed more lability in cardiac rate and poorer stabilization of rate than other infants that survived. A number of these findings have been

Geertinger emphasized sudden, brief fits of rigidity associated with pallor or cyanosis, abrupt onset of difficult breathing, and a strange look or glassy stare in infants that subsequently died of SIDS and suggested that such
infants may have had an electrolyte imbalance $(40)$.

In the week before death, and particularly in the 24 to $48 \mathrm{~h}$ period prior to death, symptoms commonly reported in SIDS infants included irritability, loss of appetite, restlessness, dyspnea, and protracted crying, sometimes of ab-
normal pitch $(2,31,38,61,69,86)$.

During the last few days of life, the rats fed magnesium deficient diets were anorexic and apathetic, but when disturbed they were jittery, tremulous, and had exaggerated startle reactions, sometimes with brief tetanic spasms and
sudden pallor (blanching of the ears). During the terminal episode, some rats emitted shrill squeaks.

Magnesium deficient rats appeared to have instability of the autonomic ervous system. They showed hypersensitivity to movement (handling) or to auditory stimuli and developed sudden loss of consciousness, prolonged apnea, cardiac rate, sinus arrest with ventricular complexes initiating from one or two foci, and sudden shifts of cardiac rate and rhythm). The normal appeartwo foci, and sudden shifts of cardiac rate and rhythm). The normal appearance of the electrocardiogram one day after near-fatal seizures corresponded to the norma electrocardiograms that Har
syncope in a future SIDS infant (46).

The most remarkable similarity between the sudden episode of magnesium deficiency and SIOS was the ability of the magnesium deficient baby rat and the human infant to suddenly coll apse and either die
pear normal for a time, and then suddenly die.

Blood chemistries before, during, and following life-threatening episodes. severe acidosis, hyperkalemia, inconstant hypercalcemia, variable abnormalities in blood sugar values, very high blood urea levels, markedly increased activity
of serum $\mathrm{LDH}$ and SGOT, and high plasma osmolality $(53,55,86)$. As the investigators have pointed out, findings from blood samples taken postmortem must be evaluated in controlled studies. Changes like those described above were found in a future SIDS infant who was stricken at home and studied during life at the
Massachusetts General Hospital (30). His initial findings included severe metabolic acidosis; elevation of serum potassium, urea nitrogen, glucose, osmolal ity, and SGOT activity; and high normal CPK plasma activity. The $T$ waves of the electrocardiogram were peaked, possibly due to hyperkalemia. The osmolal-
ity was unexplained; Brady (12) pointed out that there was no dehydration, ity was unexplained; Brady
diarrhea, or hyperpyrexia.

In the present study, the blood sampled in living $0-\mathrm{Mg}$ and $5-\mathrm{Mg}$ animals after seizures showed the nonspecific changes found in shock in man $(44,75)$, as well as the changes found in the SIDS victim during life $(30)$ and in SIDS
infants after death $(53,55,86)$. Apparently new findings in the blood chemistries associated with the seizure-shock episode of magnesium deficiency include tries associated with the seizure-shock episode of magnesium deficiency include a sharp increase in plasma osmolality, hematocrit, blood sugar, biood urea n
trogen, uric acid, and the activity of SGOT, SGPT, LDH, and creatine kinase. The increases in plasma potassium and the increased plasma enzyme activity sugThe increases in plasma potassium and the increased plasma enzyme activity sug-
gest increased membrane permeability (44). This study demonstrated the labil-
ity of plasma magnesium and the unreliabitity of plasma as a diagnostic tissue.

Few studies have been made during the seizure episode of magnesium deficiency; no chemical studies could be found in the very young mamal. In a study of adult magnesium deficient rats, Martindale and Heaton (54) noted increased plasma calcium, inorganic phosphorus, and magnesium after convulsions, with no change in plasma potassium or specific gravity, suggesting mobilization of sker etal rather than intracellular electrolytes and no appreciable hemoconcentration. In view of the higher mortality in the very young, one would expect mals.

Prolonged fasting (in cattle) has previousiy been associated with a fall in serum magnesium, frequently within the hypomagnesemic range (70). The young
magnesium deficient rats responded initially to fasting with elevated plasma magnesium deficient rats responded initially to fasting with eleva
magnesium that apparently protected them from audiogenic seizures.

Gross pathological changes following sudden death: External features. Although he may have had suboptimal growth $(61,65,67)$, the typical SIDS baby
usually appears normally nourished and hydrated, cyanotic $(8,12,87,88)$, ofen with frothy fluids in the fists may be clenched $(82,86)$, with threads caught tightly in the fingers, suggesting antemortem struggle $(8,12,69)$. The face may be covered with bedding
$(2,69)$, or may be straight down in the bedding, with pressure pallor involving the center of the face (8). Smothering can usually be ruled out $(2,8,78)$,
convulsions (91), gasping respirations (91), and other activity have been obConvulsions (91), gasping respirations (91), and other activity have been ob-
served in some infants (32); others have been observed to die quietly in a matter of minutes $(46,82,91)$.

In the animal model, some rats died after severe convulsions. Others died peacefully after circuling once, when they fell over unconscious, with tet any, apnea, and bradycardia (Fig. 5). The usual findings of the weanling rat dying of the magnesium deficiency syndrome included cyanosis, frothy fluid at forepaws, and rigid extension of the hind legs (49).

Gross pathological changes following sudden death: Internal features. $8,31,40,53,82,86-88)$. tely fill the thoracic mally expanded. Variable numbers of petechiae may be present in the pleura, thymus, and epicardium $(1,8,12,82,86-88)$ : they have been attributed to hypoxia prior to cardiac arrest and to vigorous respiratory movement (42). Most
of the lobe of a lung may be purple, poorly aerated, with varying amounts of 
edema and congestion seen on cut surface $(1,8,31,82,86-88,91)$. The blood in
the heart is fluid $(8,82,88)$, and the right heart may be distended $(8,82)$. The urinary bladder is usually empty $(8,88)$.

In this study, young 0-Mg rats dying after sudden seizure-shock episodes had gross intrathoracic pathology (Fig. 6) that was remarkably similar to that found in SIDS (Fig. 7); young magnesium deficient rats examined at other times in the magnesium deficiency syndrome in the present experiments and in other studies $(50,76)$ showed no such changes. All of the conditions influencing the pathological changes are not understood. Postmortem findings in lambs and calves dying of seizures due to magnesium deficiency have been reported as ex tensive hemorrhages coupled with acute congestion of internal organs, which were attributed to the violence of the convulsions $(70)$.

\section{PART II. TESTING THE HYPOTHESIS IN HUMAN SUBJECTS (A REVIEW OF PREVIOUSLY REPORTED STUDIES) \\ A. TESTIHG THE HYPOTHESIS DIRECTLY.}

\section{Studies in SIDS cases and controls.}

To learn whether or not there is an absolute or relative deficiency of magnesium in SIDS, one would analyze appropriate diagnostic tissues in SIDS and control infants for magnesium and interrelated minerals and compare the results. Accordingly, several investigators have analyzed blood plasma, liver, and vitreous humor and have found no abnorn
as recently reviewed $(8,27,88)$.

Plasma, liver, and vitreous humor are inappropriate tissues to establish the diagnosis of magnesium deficiency post mortem. Plasma magnesium is extremely labile, sharply increasing during seizures and after death in childcrease during acute magnesium deficiency $(20,27)$. Swift and associates $(80)$ crease during acute magnesium deficiency $(20,27)$. Swift and associates (80) found that the magnesium level of vitreous humor in human infants are age-
related, with highest levels in the neonate, and with a wide range of values for each age group.

\section{Studies in an animal model for the human infant of SIDS age}

We studied an animal model to determine the optimal tissue and conditions needed to assess the magnesium status of a young mammal after death. (27). The literature regarding changes in mammal ian tissues in magnesium deficiency reveals conflicting results. No studies of the vitreous humor in any mammal with
biochemically established magnesium depletion could be found.

Vitreous magnesium. We (27) measured vitreous magnesium in $0-M g$ and in $100-M g$ rats (the latter represents 2.5 times the recomnended daily allowance for growing rats). The values all fell within a narrow range, and there was considerable overlapping of individual values among the three groups. Grouped data showed a significant difference between $0-\mathrm{Mg}$ experimental animais and
$100-\mathrm{Mg}$ controls, but not laboratory chow controls. The vitreous magnesium did not reflect the known degree of magnesium deficiency.

The optimal tissue and conditions found. Bone was found to be the best tissue to determine whether or not a young manmal has adequate stores. Since different bones from the same animal did not all have the same mineral composition, one bone must be selected for analysis. The irregular distribution of magnesium within a single bone warrants the study of one entire bone (27).

\section{B. TESTING THE HYPOTHESIS INDIRECTLY.}

The results of some studies of magnesium metabolism in young mothers, in fants, and children can be matched against known facts in the sudden infant death syndrome; this constitutes an indirect test for the hypothesis. The plasma and urinary magnesium values and the results of the parenteral magnesiom
load test were determined.

The parenteral magnesium load test. This test has been used extensively to assess the magnesium status of individuals during life $(22,23,25,45,83)$ It is essentially a test of tissue saturation of magnesium, based on the fact that the normal kidney regulates the body stores of magnesium, promptly excret-
ing an excess, but avidiy retaining the mineral during a deficiency state (45,
83). It was introduced because al though low plasma magnesium values usually indicate magnesium deficiency, normal plasma magnesium values are unreliable $(21,22,58)$

A preload collection of urine is made; $0.5 \mathrm{mEq}$ of magnesium/ $\mathrm{kg}$ of body weight is given parenterally; postload urine is collected (the time depending on the age and maturity of the patient; it is usually $24 \mathrm{~h}$ for children); urinary magnesium is measured; and the percent retention is calculated. Retention of up to $40 \%$ of the load is usually considered normal for children over one ficiency.

For example, in a study of malnourished 25 -month-old Thai children weighing about $7 \mathrm{~kg}, 15$ with known mineral losses through prolonged severe antecedent diarrhea retained $73 \%$ of the load, while 15 with little or no diarrhea retained only $27 \%$ initially. On day 70 when clinically well, the mean retention of the entire group was $17 \%$. The test appeared
expected magnesium stores in the children (22)

\section{STUDIES IN HUMAN MOTHERS}

\section{A study in well nourished Thai mothers.}

A study was made to assess the magnesium stores of postpartum Thai women whose typically oriental diets included an abundance of magnesium-rich foods, such as nuts, legumes and other green vegetables, and shrimp (23). Their magnesium status was evaluated by plasma and urinary preload magnesium values and
by the parenteral magnesium load test, in which the dose of $0.4 \mathrm{mEq}$ of magnesium/ $\mathrm{kg}$ of estimated lean body weight was given.

Nulliparous controls retained $22.6 \pm 6 \%(9)$, and postpartum women, 36.7 $+4.7 \%$ (24) of the magnesium load; the numbers represent the mean, SEM (number in sample). Despite high parity and prolonged lactation in some, there was no obligatory retention; over one-third of the patients retained a mean of only $9 \%$ of the load.

\section{A study of low income urban American mothers.}

A subsequent study was made to assess the magnesium status in 185 postpartum women in St. Louis City and St. Louis County Hospitals. The patients $51 \%$ of the parenteral load, with a range of 0 to $100 \%$.

Patients with high retention of magnesium reported a high intake of refined starches and fats, a magnesium-poor diet that was fairly typical of the diets of the low income young urban women. Patients with high retention had
lower plasma magnesium and lower preload urinary magnesium values than patients
who retained less than $40 \%$ of the load.

The strongest evidence for magnesium deficiency, mean retention exceeding $90 \%$ of the parenteral magnesium load, was found in young mothers of twins and in multiparas less than 17 years of age; this appears to reflect the high
magnesium requirement of adolescent growth and multiple or repeated pregnancies.

Multiparous mothers over 30 years of age had the longest interval since the previous pregnancy and the lowest retention value, $32.3 \pm 5.8 \%$ (18).

Maternal factors in SIDS.

In the light of the foregoing, it is useful to consider some observations
SIOS.

1. SIDS has been reported predominantly in Western cultures (8). In Califor nia (48), Oriental people had the lowest incidence of SIDS.

2. The incidence of SIDS is high among economically depressed urban dwellers, and lower in predominantly agricultural areas $(8,39)$.

3. There is a significantiy increased risk for young mothers of increased
parity (39)

4. The incidence is high if mothers are less than 20 years of age, lower in older mothers (48).

5. Twins have a higher risk than singleton births $(8,40,48,88)$, and the risk further increases for triplets (48).

6. There is a significant recurrence rate in families; it is not thought to involve any specific inheritance mechanisms (38).

A possible interpretation of maternal factors in SIDS. The Tha i mothers represent the Oriental whose diet is rich in magnesium and other minerals. They serve as a control for the low income urban American women, whose diet is often poor in magnesium. The high requirements during adolescent growth and repeated pregnancies may not be met from such a diet. The heaviest demands for magnesium would be during twin or multiple pregnancies in young women, or repletion of essential nutrients. This might explain the high incidence in infants born to young multiparas, in twins, and the recurrence of SIDS in families.

\section{STUDIES IN HUMAN INFANTS AND CHILDREN}

\section{Studies in malnourished young children with enteric disorders.}

Profound losses of magnesium occur during diarrhea and during catabolism associated with starvation $(45,70,83)$. In some areas of the tropics and subtropics, severe malnutrition with antecedent enteritis constitutes a major ped-
jatric problem in 1 to 4 -year-old children who of ten weigh only 6 to $9 \mathrm{~kg}$ (15$17,84)$.

For many years (84), the therapy of severely malnourished children included gavage-fed milk protein hydrolysates, high in protein, calcium, and phosphorus, but poor in magnesium. Vitamins and minerals other than magnesium were added to the therapy. During the phase of accelerated protein anabolism, when the childrer appeared to be recovering, some died suddenly and without apparent reason. at autopsy included a little fluid in the lungs; no cause of death was found 84).

Subsequent studies of malnourished children in the tropics have demonstrated magnesium deficiency and other problems $(5,74)$. Low concentration of magnesium in plasma $(7,16,21)$, urine $(7,21,52,58)$ and muscle $(16,21,56,58)$; high retention of parenterally administered magnesium (22), and long-continued positive magnesium balance during recovery from malnutr
dicate a true deficit of magnesium $(5,16,21,58,85)$.

Signs and symptoms linked with hypomagnesemia in young infants and children. out of touch with surroundings (63); extreme irritability (63); jumping at the out of touch with surroundings (63); extreme irritability (63); jumping at the
slightest noise (63); poor sleep (63); apnea while sucking a bottle (21); fixed staring (21) or rolling the eyes upward $(7,16,21,63)$; tremors or twitching $(7,16,21,63)$; marked hypertonia $(7,16,21)$ or hypotonia $(63)$; and tomic or clonic, localized or generalized, seizures $(7,16,21,45,63,73)$.

Results of magnesium therapy. For magnesium deficient children already $45,52,73)$ and sometimes appeared to be lifesaving $(5,15-17,63,83,85)$.

\section{An animal model to study the phenomenon of sudden death during the period of}

Weanling rats were fed low protein diets to serve as models for malnourished children. They were then refed high dietary casein without added magnesium. They were gaining weight and appeared to be recovering well when they ein with added magnesium grew at accelerated rates and recovered uneventfully (20).

\section{Comparison of the above magnesium deficient infants and children to infants
that subsequently die of S1DS.}

The age difference. The magnesium deficiency syndrome would be expected to be more acute and more lethal in young infants of SIDS age than in $1-$ to 4 
year-old children. And it is evident that the nonspecific signs and symptoms linked with hypomagnesemia in young infants and children are essentially the same as the signs and symptoms linked with SIDS.

Depletion resulting from growth in a subject with poor magnesium reserves. Premature or low birth weight infants, over-represented in SIDS, have low magnesium requirements to support "catch-up growth" (24). Sudden infant death is more common in bottle-fed than breast-fed infants $(66,88)$. Porter $(66)$ believes that SIDS infants receive excess protein from reconstituted dried cow's milk and infant cereal preparations. Such foods are also rich in calcium and phosphorus. Artificially fed infants might develop a critical imbalance rethe the infat if the dect the infant if the mother were malnourished, as in Templeman's series flected in magnesium-poor milk $(41,90)$, which may lead to magnesium deficiency in nursing offspring $(90)$

Studies in American infants 1-6 months of age with possible near miss episodes

We have been utilizing the parenteral magnesium load test to assess the magnesium stores of infants referred to the Cardinal Glennon Memorial Hospital for Children, St. Louis, Mo. Of these, some were referred because of recent episodes similar to near-miss episodes of SIDS.

In the first series (26), a group of seven infants averaging 8 weeks of age presented with one to three life-threatening episodes. Signs and symptoms included: apnea; sudden loss of consciousness; bradycardia; tonic rigidity, followed by flaccidity; dyspnea; a dazed look; flushing; drooling; and sweat-
ing. This group retained a mean of $88 \%$ of the parenteral magnesium load, despite preload magnesium treatment during the acute episode in two.

In a larger series since December, 1974, 25 infants over one month of age who were studied because of episodes similar to near miss episodes retained 60 to $100 \%$ of the load, even though some of them had received magnesium therapy. prior to the load test. However, some other infants with similar episodes had lower retention of the magnesium loads.

Comment. These magnesium load studies were made in infants 1 to 6 -months of age, the age at which SIDS usually occurs. The symptoms exhibited were nonspecific, but were typical of those that may occur during the near miss episode. Some infants had repeated episodes. Although the similarity of the that syndromes, acute magnesium deficiency and SIDS, is striking, we believe with magnesium deficiency in SIDS, if indeed SIDS is caused by a mineral imbalance (28).

\section{CONCLUSIONS.}

The cause of SIDS remains unknown. We believe that further, more appropriate testing of SIDS infants and of carefully selected controls is ed to determine whether or not magnesium deficiency is a major contributing cause of SIDS. If so, since magnesium operates in conjunction with other minerals in the body, we would expect to find an associated mineral imbalance.

\section{REFERENCES AND NOTES}

1. Adelson, L.: A forensic pathologist looks at sudden and unexpected death in infancy and childhood. In: C. B. Reiner: A Research Conference on 1976, pp. 1-25. (Sponsored by: Ohio Dept. Health; Ohio Chapter Am. Acad. Pediatrics; and the Children's Hospital, Columbus, Ohio, 1976).

2. AdeIson, L. and Kinney, E.R.: Sudden and unexpected death in infancy and childhood. Pediatrics, 17: 663 (1956).

3. Aitken, M.M. and Sanford, J.: Experimental anaphylaxis in cattle. J. Comp. Pathol., 79: 131 (1969).

4. Alcock, N.W. and Shils, M.E.: Comparison of magnesium deficiency in the rat and mouse. Proc. Soc. Exp. Biol. Med., 146: 137 (1974).

5. Alleyne, G.A.O.: Mineral metabolism. In: R.E. 01son: Protein-Calorie Malnutrition, pp. 201-212 (Academic Press, New York and London, 1975). 6. Austen, K.F.: Systemic anaphylaxis in the human being. N. Engl. J. Med.,
291: 661 (1974).

7. Back, E.H., Montgomery, R.D., and Ward, E.E.: Neurological manifestations of magnesium deficiency in infantile gastro-enteritis and malnutrition. 37: 106 (1962).

8. Beckwith, J.B.: The Sudden Infant Death Syndrome, pp. 8-10, 17-20, 27. (U.S. Dept. Health, Education, and Welfare, Pub. No. (HSA) 75-5137, U.S

Bergman, A.B.: Physiology discussion. In: A. B. Bergman, J. B. Beckwith and C. G. Ray: Sudden Infant Death Syndrome. Proceedings of the Second International Conference on Causes of Sudden Death in Infants, p. 204 (University of Washington Press, Seattle and London, 1970).

10. Bertelli, A.: Preface. In: A. Bertelli and N. Back: Shock: Biochemic a], Pharmacological, and Clinical Aspects. Proceedings of the International Symposium on Shock, Como, Italy, Oct. 10-11, 1969, p. v (Plenum Press, New York and London, 1970).

11. Booth, B.H. and Patterson, R.: Electrocardiographic changes during human anaphylaxis. J. Am. Med. Assoc., 211: 627 (1970).

12. Brady, J.P.: In: Case records of the Massachusetts General Hospital. Case 31-1973. N. Eng1. J. Med., 289: 261 (1973).

13. Brasher, G.W. and Sanchez, S.A.: Reversible electrocardiographic changes associated with wasp sting anaphylaxis. J. Am. Med. Assoc., 229: 1210,

14. Brown, J.K.: Convulsions in the newborn period. Dev1. Med. Child. Neurol
15: 823 (1973). Cadde11, J.L.: Magnesium in the therapy of protein-calorie malnutrition of childhood. J. Pediatr., 66: 392 (1965).
16. Cadde11, J.L. and Goddard, D.R.: Studies in protein-calorie malnutrition. I. Chemical evidence for magnesium deficiency. N. Engl. J. Med., 276:

17. Cadde 1 , J.L.: Studies in protein-calorie mainutrition. II. A doub?eblind clinical trial to assess magnesium therapy. N. Eng1. J. Med., 276 535 (7967).

18. CaddelT, J.L.: Magnesium deficiency in protein-calorie malnutrition. A follow-up study. Ann. N. Y. Acad. Sci., 162: 874 (1969).

19. Cadde11, J.L.: Hypothesis: Magnesium deprivation in sudden unexpected infant death. Lancet, 2: 258 (1972).

20. Cadde11, J.L., 01son, R.E.: Effect of dietary protein and magnesium on selected ATP phosphotransferases and neuromuscular behavior in young rats
J. Nutr., 103: $1385(1973)$.

21. Caddell, J.L. and 01son, R.E.: An evaluation of the electrolyte status of malnourished Thai children. J. Pediatr., 83: 124 (1973).

22. Cadde11, J.L., Suskind, R., Sillup, H., and 01son, R.E.: Parenteral magnesium load evaluation of malnourished Thai children. J. Pediatr. 83 129 (1973).

23. Cadde11, J.L., Ratananon, N., and Trangratapit, P.: Parenteral magnesium load tests in postpartum Thaj women. Am. J. Clin. Nutr., 26:612 (1973). 24. Caddell, J.L.: Magnesium in the nutrition of the child. Clin. Pediatr.,
13: 263 (1974).

25. Caddell, J.L., Saier, F.L., and Thomason, C.A.: Parenteral magnesium load tests in postpartum American women. Am. J. Clin. Nutr., 28: 1099 (1975).

26. Caddell, J.L., Byrne, P.A., Triska, R.A., and McElfresh, A.E.: The magnesium load test. III. Correlation of clinical and laboratory data in
infants from one to six months of age. Clin. Pediatr., 14:478 (1975).

27. Caddell, J.L. and Scheppner, R.: The postmortem diagnosis of magnesium deficiency: Studies in an animal model for the human infant. J. Forensic Sci., 23: 335 (1978).

28. Cadde11, J.L., Byrne, P.A., and Scheppner, R.: Parenteral magnesium load testing in infants from one to twelve months of age. In preparation.

29. Caddell, 3.L.: An amplified hypothesis: Magnesium and zinc deficiency and cadmi um excess in the sudden infant death syndrome. In preparation.

30. Castleman, B.: Case records of the Massachusetts General Hospital. Case 31-1973. N. Engl. J. Med, , 289: 261 (1973).

37. Coe, J.I. and Hartman, E.E.: Sudden, unexpected death in infancy. J. Pediatr. 56: 786 (1960)

32. Cooke, R.T. and Welch, R.G.: A study in cot death. Brit. Med. J. 2: 1549 (1964).

33. Coombs, R.R.A.:..In: F.E. Camps and R.G. Carpenter: Sudden and Unexpected Deaths in Infancy (Cot Deaths). Report of the Proceedings of the Sir Samuel Bedson Symposium held at Addenbrooke's Hospital, Cambridge, on 17 and 18 Apri1, 1970, pp. 16-22, 79 (John Wright and Sons, Ltd., Bristol, 1972). 34. Dancis, J., Springer, D., and Cohlan, S.Q.: Fetal homeostasis in maternal
malnutrition. II. Magnesium deprivation. Pediatr. Res., 5: 131 (1971).

35. Emery, J.L. and Crowley, E.M.: Clinical histories of infants reported to
coroner as cases of sudden unexpected death. Br. Med J, 2: 1518 (1956)

36. Esplin, D.W. and Zablocka-Esplin, B.: Central nervous system stimulants.
Strychnine. In: L.S. Goodman and A. Gilman: The Pharmacological Basis Strychnine. In: L.S. Goodman and A. Gilman: The Pharmacological Basis of Therapeutics, Ed. 4, pp. 348-350 (Macmillan Co., London and Toronto,
1970).

37. Farris, E.J.: Breeding of the rat. In: E. J. Farris and J. Q. Griffith Jr.: The Rat in Laboratory Investigation. Ed. 2, pp. 1-4 (Hafner, New York, 1963).

38. Froggatt, P., Lynas, M.A., and MacKenzie, G.: Epidemiology of sudden unexpected death in infants ('cot death') in Northern Ireland. Br.J. Prev. Soc. Med., 25: 119 (1971).

39. Froggatt, P., Lynas, M.A., and Marshall, T.K.: Sudden unexpected death in infants ('cot death'). Report of a collaborative study in Northern

40. Geertinger, P.: Sudden Death in Infancy, pp. 14-23 (Charles C Thomas, Springfield, ill., 1968).

41. Greenwald, J.H., Dublin, A., and Cardon, L.: Hypomagnesemic tetany due to excessive lactation. Am. J. Med., 35: 854 (1963).

42. Gunderoth, W. G.: The significance of pulmonary petechiae in crib death. Pediatrics, 52: 601 (1973).

43. Hanashiro, P.K. and Weil, M.H.: Anaphylactic shock in man. Arch. Intern. Med., 119: 129 (1967).

44. Hardaway, R.M., III.: Clinical Management of Shock. Surgical and Medical pp. 269-272 (Charles C Thomas, Springfield, 111., 1968).

45. Harris, I. and Wilkinson, A.W.: Magnesium depletion in children. Lancet,
2: 735 (197l).

6. Harris, L.E. In: F.E. Camps and R. G. Carpenter: Sudden and Unexpected Deaths in Infancy (Cot Deaths). Report of the Proceedings of the Sir Samuel Bedson Symposium held at Addenbrooke's Hospital, Cambridge, on it
and 18 April, 1970, pp. 39-40 (John Wright and Sons, Bristol, 1972). 
47. Hasselmeyer, E.G.: The Sudden Infant Death Syndrome Research Program of the National Institute of Child Health and Human Development, Pregnancy and Infancy Branch. (U.S. Dept. Health, Education and Welfare, DHEW Publication No. (NIH) 77-1436, Washington, D.C., DHEW PublicüHealth Service, National Institutes of Health, 1977).

48. Kraus, J.F. and Borhani, N.O.: Post-neonatal sudden unexplained death in California. A cohort study. Am. J. Epidemiol. 95: 497 (1972).

49. Kruse, H.D., Orent, E.R., and McCollum, E.V.: Studies on magnesium deficiency in animals. I. Symptomatology resulting from magnesium depriva-
tion. J. Biol. Chem. $96: 519$ (1932).

50. Kulka, J.P.: Microcirculatory impairment as a factor in inflammatory tissue damage. Ann. N.Y. Acad. Sci., 116: 1018 (1964).

51. Layton, J.J. and Cameron, J.M.: Post-mortem findings in anaphylactic shock. Practitioner, 206: 383 (1971).

52. Linder, G.C., Hansen, J.D.L., and Karabus, C.D.: Metabolism of magnesium and other inorganic cations and of nitrogen in acute kwashiorkor. Pediatrics, 31: 552 (1963).

53. Marshall, T.K.: The Northern Ireland study: Pathological findings. In: A. B. Bergman, J. B. Beckwith, and C. G. Ray: Sudden Infant Death Syndrome. Proceedings of the Second International Conference on Causes of Seattle and London, 1970).

54. Martindale, L. and Heaton, F.W.: Magnesium deficiency in the aduit rat. Biochem. J. 92: 119 (1964).

55. McGaffey, H.L.: Crib death: Metabolic disturbances reflected in laboratory studies. Am. J. Clin. Pathol., 54: 270 (1970)

56. Metcoff, J., Frank, S., Antonowicz, I., Gordillo, G., and Lopez, E.: Relations of intracelluiar ions to metabolite sequences in muscle in kwashiorkor. Pediatrics, 26: 960 (1960).

57. Metson, A.J., Saunders, W.M.H., Collie, T.W., and Graham, V.W.: Chemical composition of pastures in relation to grass tetany in beef breeding cows. New Zealand J. Agric. Res., 9: 410 (1966).

58. Montgomery, R.D.: Magnesium metabolism in infantile protein malnutrition. Lancet, 2: 74 (1960)

59. Moore, F.D.: Physiological indices of hypoperfusion in man. In: D. Shepro and G. P. Fulton: Microcirculation as Related to Shock. pp. 233 245. (Academic Press, New York and London, 1968).

60. McCance, R.A. and Widdowson, E.M.: The Composition of Foods. Medical Re search Council, S.R.S. 297, London, Her Majesty's Stationery Office, $1967,270 \mathrm{pp}$.

61. Naeye, R.L., Ladis, B., and Drage, J.S.: Sudden infant death syndrome. A prospective study. Am. J. Dis. Child., 130: 1207 (1976).

62. Orent, E.R., Kruse, H.D., and McCollum, E.V.: Studies on magnesium deficiency in animals. II. Species variation in symptomatology of magnesium deprivation. Am. J. Physiol., 101: 454 (1932).

63. Paunier, L., Radde, I.C., Kooh, S.W., Cohen, P.E., and Fraser, D.: Primary hypomagnesemia secondary to hypocalcemia in an infant. Pediatrics, 41: 385 (1968).

64. Peterson, D.R.: Sudden, unexpected death in infants, an epidemiologic study. Am. J. Epidemiol., 84: 478 (1966).

65. Peterson, D.R., Benson, E.A., Fisher, L.D., Chinn, N.M., and Beckwith, J.B.: Postnatal growth and the sudden infant death syndrome. Am. J. Epidemiol., 99: 389 (1974)

66. Porter, A.M.W. In: F. E. Camps and R. G. Carpenter: (See Ref. 33), p. 74.

67. Protestos, C.D., Carpenter, R.G., McWeeny, P.M., and Emery, J.L.: Obstetric and perinatal histories of children who died unexpectedly (cot death) Arch. Dis. Child., 48: 835 (1973).

68. Reid, Gladys M., Te Aroha, New Zealand, 1978. Personal communication.

69. Richards, I.D.G. and MCIntosh, H.T.: Confidential inquiry into 226 consecutive infant deaths. Arch. Dis. Child, , 47: 697 (1972).

70. Rook, J.A.F. and Storry, J.E.: Magnesium in the nutrition of farm animals Nutr. Abstr. Rev, 32: 1055 (1962).

71. Salet, J. and Fournet, J.-P.: Les hypomagnêsémies de l'enfant. Annales de Pediatrie 47: 39 (1971).

72. Salk, L., Grellong, B.A., and Dietrich, J.: Sudden infant death. Normal $219(1974)$

73. Savage, D.C.L. and McAdam, W.A.F.: Convulsions due to hypomagnesaemia in an infant recovering from diarrhoea. Lancet, 2: 234 (1967).

74. Sanstead, H.H.: Mineral metabolism in protein malnutrition. In: R.E. 01 son. (See Ref. 5), pp. 213-220.

75. Shoemaker, W.C.: Shock. Chemistry, Physiology, and Therapy. pp. 120196 (Charles C Thomas, Springfield, I11., 1967).

76. Smith, B.S.W. and Nisbet, D.I.: Biochemical and pathological studies on magnesium deficiency in the rat. I. Young animals. J. Comp. Pathot., 78: $149(1968)$.
77. Steinschneider, A.: Possible cardiopulmonary mechanisms. In: A. B. Bergman, J. B. Beckwith, and C. G. Ray: Sudden Infant Death Syndrome. Proceedings of the Second International Conference on Causes of Sudden Death in Infants, pp. 181-198 (University of Washington Press, Seattle and London, 1970).

78. Steinschneider, A.: Prolonged apnea and the sudden infant death syndrome Clinical and laboratory observations. Pediatrics, 50: 646 (1972).

79. Stevens, L.H.: Sudden unexplained death in infancy. Am. J. Dis. Child., 110: 243 (1965).

80. Swift, P.G., Worthy, E., and Emery, J.L.: Biochemical state of the vitreous humor in infants at necropsy. Arch. Dis. Child., 49: 680 (1974)

81. Technicon Instrument Corp. (Technical Publication No. UA-3-0306B31), Tarrytown, New York 1050i, March (1976).

82. Templeman, C.: Two hundred and fifty-eight cases of suffocation of infants. Edinb. Med. J., 38: 322 (1892).

83. Thoren, L.: Magnesium deficiency in gastrointestinal fluid loss. Acta Chir. Scand. Suppl. 306: i (1963).

84. Trowell, H.C., Davies, J.N.P., and Dean, R.F.A.: Kwashiorkor. pp. 71, 114-115, 186-195. (Edward Arnold, London, 1954)

85. Unsigned: Leading Articie: Magnesium and malnutrition. Lancet, 1: 712 (1967).

86. Valdes-Dapena, M.D.: SIDS records, Philadelphia, 1959-1963, by permission

87. Valdes-Dapena, M.A.: Sudden and unexpected death in infancy: A review of the world literature, 1954-1966. Pediatrics, 39: 123 (1967).

88. Valdes-Dapena, M.A.: Sudden and Unexplained Infant Death. 1970 through 1975. An Evolution in Understanding. pp. 1-29 (U.S. DHEW, Bureau of con munity Services, DHEW Pub. No. (HSA) 78-5255, Washington, D.C., 1978).

89. Vaughan, V.C., III: Growth during the first year. In: V. C. Vaughan, III and R. J. Mckay: Textbook of Pediatrics, 10th Ed., p. 22 (W. B. Saunders Philadelphia, Pa., 1975)

90. Wang, F.L., Wang, R., Khairallah, E.A. and Schwartz, R.: Magnesium depletion during gestation and lactation in rats. J. Nutr., 101: 1201 (1971)

91. Werne, J. and Garrow, I.: Sudden apparently unexplained death during infancy. II. Pathologic findings in infants observed to die suddenly. Am. J. Pathol, 29: 817 (1953)

92. Wiggers, C.J.: Physiology of Shock. p. 31 (Commonwealth, N. Y., 1950).

93. Yaffe, S.J., Chairman, Committee on Drugs, American Academy of Pediatrics: Anaphylaxis. Pediatrics, 51: 136 (1973).

94. The late Arthur E. McElfresh, M.D., Professor of Pediatrics, gave this project his unremitting support. The excellent technical assistance of
Miss Rita Scheppner is gratefuliy acknowledged. We thank Dr. Virginia $H$. Peden for reviewing the manuscript; Dr. Robert E. 01son, Dr. Anthony $N$ Martinosi, and Dr. Ky Park for the use of equipment; Dr. Donald Parker for supervising SMAC analyses; Mr. Arnold Heidnreder, Central Institute for the Deaf, St. Louis, for measuring sound pressure levels; and Miss Patricia Grbcich for compiling data.

95. This work was presented in part at the annual meeting of the Midwest Pediatric Cardiology Society, Minneapolis, Minn., September 22, 1978.

96. This research was supported by the Missouri Heart Association; The Life Seekers of St. Louis, Mo.; Mr. Ward Melville of Stony Brook, N. Y.; and Mrs. Charles B. Jennings of Chestnut $\mathrm{Hill}, \mathrm{Pa}$.

97. Correspondence should be addressed to: Dr. Joan L. Caddell, St. Louis University School of Medicine, 1402 South Grand Boulevard, St. Louis, Mo. 63104, U.S.A.

98. Received for publication March 30, 1978.

99. Accepted for publication July 27, 1978

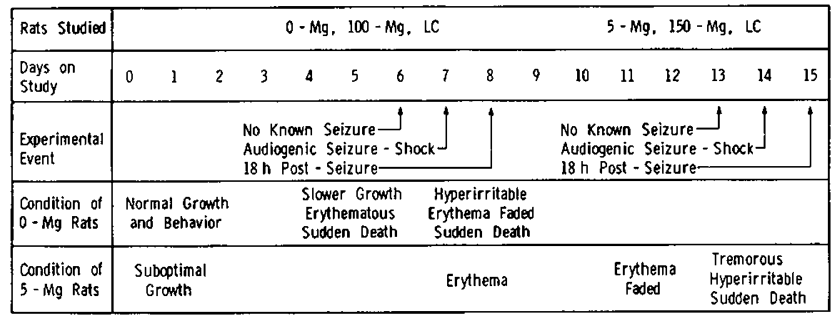

Fig. 1. The plan to study the seizure-shock episode in magnesium deficient weanling rats. The acute syndrome was studied at one week in rats fed 0 added magnesium and $20 \%$ case in $(0-\mathrm{Mg})$, and their controls fed a similar diet with $100 \mathrm{mg}$ of added magnesium $/ 100 \mathrm{~g}$ dry diet $(100-\mathrm{Mg})$, or laboratory chow (LC). The attenuated deficiency was studied at two weeks in rats fed $5 \mathrm{mg}$ of added magnesium and $40 \%$ casein $(5-\mathrm{Mg})$, and in controls fed a similar diet with
$150 \mathrm{mg}$ of added magnesium $(150-\mathrm{Mg})$, or $L C$. 


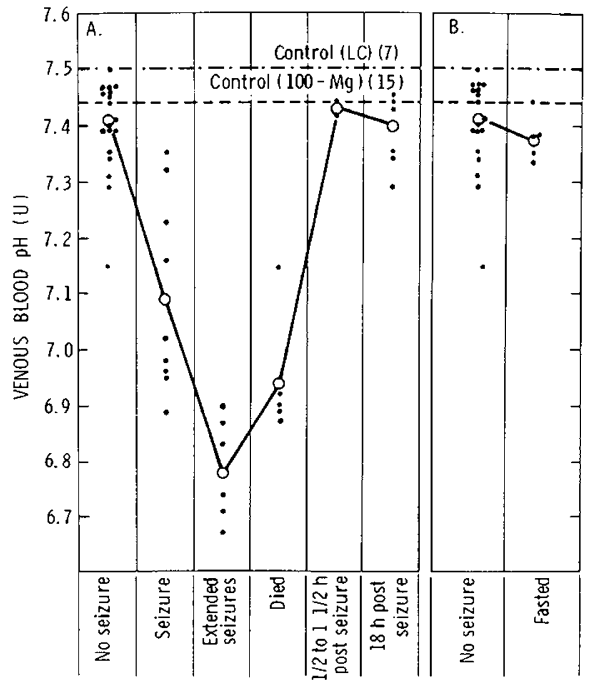

O Mean value

- Individual value

Fig. $2 \mathrm{~A}$. Venous blood $\mathrm{pH}$ in acute magnesium deficiency. Mean values for $100-\mathrm{Mg}$ controls, $7.44 \pm 0.01$ and LC controls, $7.50 \pm 0.01$, are shown by horizontal 1ines. Numbers in parentheses indicate the numer of samples making up the mean. Values for acutely deficient (0-Mg) rats with no knom seizures were obtained on day 6 , and were normalizing at the preseizure level $18 \mathrm{~h}$ post seizures.

Fig. $2 \mathrm{~B}$. Venous blood $\mathrm{pH}$ in $\mathrm{O}-\mathrm{Mg}$ rats before and after a $24 \mathrm{~h}$ fast, showing no difference from control values.

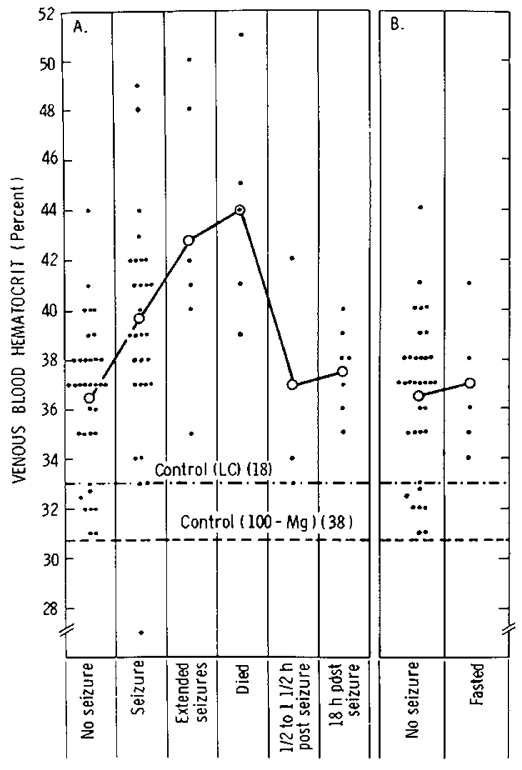

O Mean value

- Individual value

Fig. $3 \mathrm{~A}$. Venous blood hematocrit in percent in acute magnesium deficienMean were significantly higher than in $100-\mathrm{Mg}$ controls $(P<0.001)$ and after death $(P<0.001)$.

Fig. $3 \mathrm{~B}$. The hematocrit did not change during the $24 \mathrm{~h}$ fast.

Fig. 5. Electrocardiograms were taken in rats that weighed $28-32 \mathrm{~g}$ at the onset of the study. Tracings were taken at twice normal standard $(20 \mathrm{~mm} / \mathrm{mv})$ and at twice nomal paper speed $(50 \mathrm{~mm} / \mathrm{sec})$ in supine rats that were sedated in A) and $B$ ), but studied with no sedation in tetanic, apneic, unconscious $\mathrm{O}-\mathrm{Mg}$ animals during the seizure-shock episode ( $C$ through $F$ ). The tracings of $100-M g$ controls in A) and the $0-M g$ rats with no known seizures in $B$ ) had rates of 575 and $480 / \mathrm{min}$., respectively, and the electrical patterns were indistinguishable. In C) and D), during the seizure-shock episode, there was sinus ar rest, and the ventricular rate precipitously dropped to about one-third of the normal rate. Apnea persisted, bradycardia was progressive, and the rats died. In D) and E), the ventricular complexes were initiated from two electrical foci. In 0 ) and F), during the early recovery period, the heart rate and rhythm improved as both animals spontaneously resumed respirations. Spiked electrical seizures (not shown).

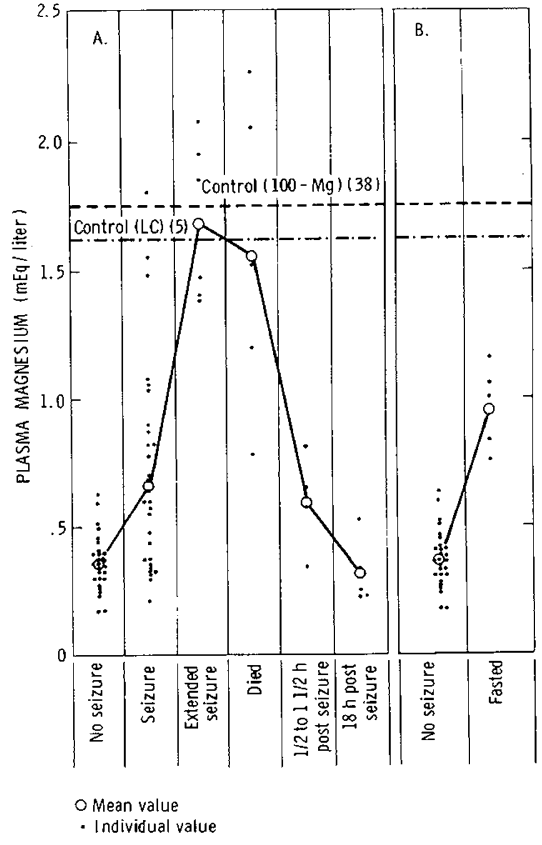

Fig. 4 A. Plasma magnesium concentrations in $\mathrm{mEq} / \mathrm{liter}$ in acute magnesium Fig. 4 A. Plasma magnesium concentrations in mEq/ 1 ter in acute magnesium
deficiency. Mean values for $100-\mathrm{Mg}$ controls, $1.75 \pm 0.03$ and $\mathrm{LC}$ controls, 1.62 +0.03 , were not significantly different. The magnesium concentration of $0-\mathrm{Mg}$ $100-\mathrm{Mg}$ controls $(\mathrm{P}<0.001)$ but during extended seizures or immediately after fatal seizures, the deficient animals had normal magnesium values. The concentration of magnesium was at the preseizure level $18 \mathrm{~h}$ after seizures.

Fig. $4 \mathrm{~B}$. The plasma magnesium value increased during fasting to $0.96+$ $0.06 \mathrm{mEq} / \mathrm{liter}(\mathrm{P}<0.001)$
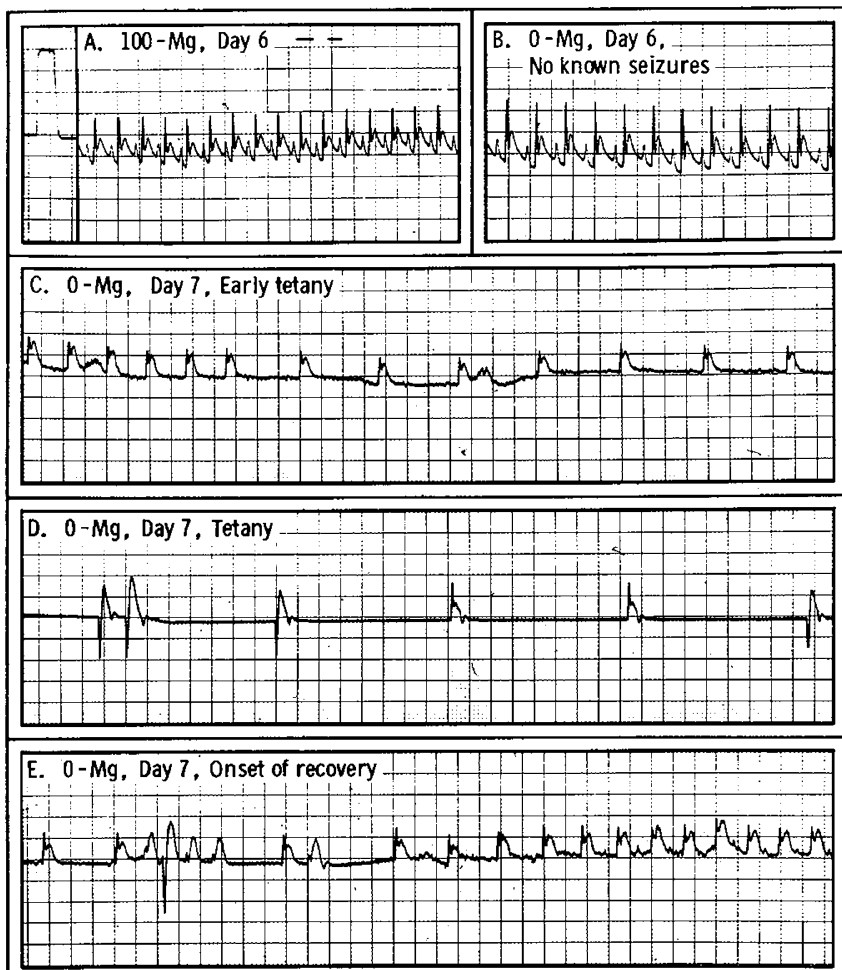

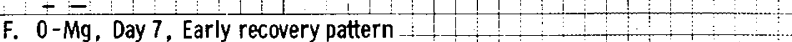

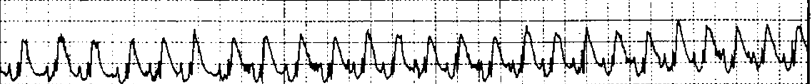




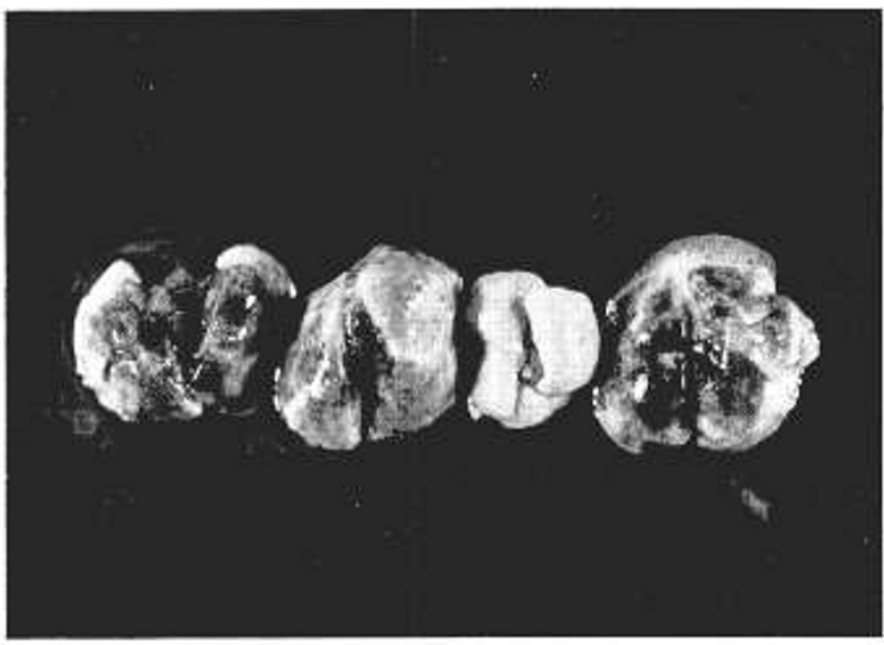

Fig. 6. From left to right: the first, second, and fourth lungs were from $0-M g$ rats that died after a tetanic-apneic episode that was provoke
gentle handling only, and the third lungs were from a $100-M g$ control.

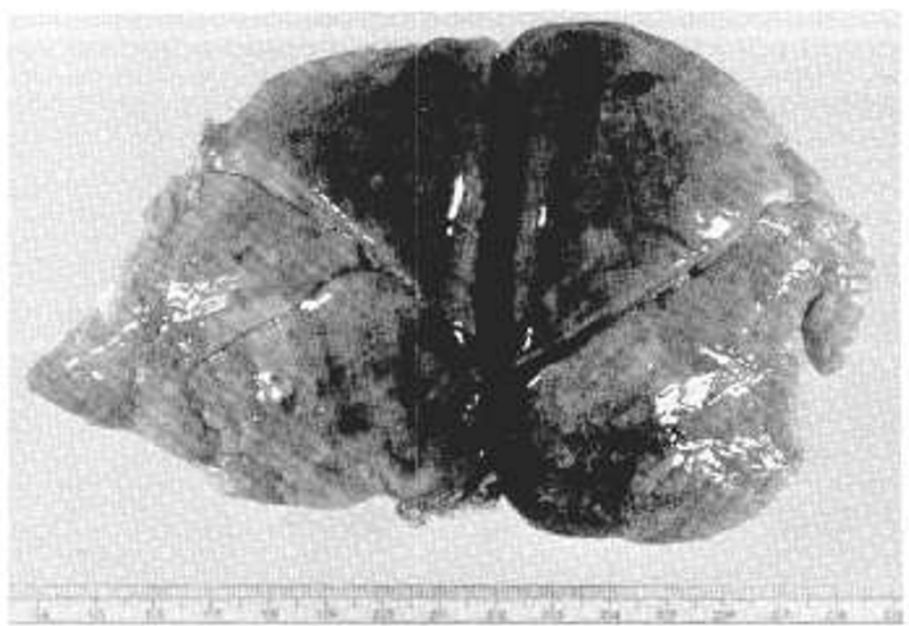

Fig. 7. Lungs of an 11-week-old white male infant who was found blue and apneic in his crib two hours after his mother had last seen him and thought that he was normal. He failed to respond to resuscitation. Autopsy (A75-365) was performed within $6 \mathrm{~h}$ of discovery by Dr. George E. Gantner, M.D., Chief appearance, external petechiae, and were congested throughout, with posteriorly located atelectasis. The diagnosis was the sudden infant death syndrome.
TABLE 1

COMPOSITION OF THE PURIFIED DIETS

\begin{tabular}{|c|c|c|}
\hline & $\begin{array}{l}\text { Control } \\
100-\mathrm{Mg}\end{array}$ & $\begin{array}{c}\text { High protein control } \\
150-\mathrm{Mg}\end{array}$ \\
\hline & \multicolumn{2}{|c|}{$\mathrm{g} / 100 \mathrm{~g}$ of diet } \\
\hline Casein $^{7}$ & 20.0 & 40.0 \\
\hline Corn $0 i 1^{2}$ & 5.5 & 5.5 \\
\hline Glucose monohydrate ${ }^{3}$ & 68.24 & 48.08 \\
\hline Mineral mix ${ }^{4}$ & 4.26 & 4.42 \\
\hline Choline chloride ${ }^{5}$ & 0.30 & 0.30 \\
\hline L-cystine ${ }^{5}$ & 0.20 & 0.20 \\
\hline Water-soluble vitamins ${ }^{6}$ & 1.00 & 1.00 \\
\hline Fat-soluble vitamins ${ }^{7}$ & Total $\frac{0.50}{100.00}$ & $\frac{0.50}{100.00}$ \\
\hline
\end{tabular}

1. Vitamin-free test casein, Mogul Corp., Madison, Wis.

2. Mazola, Best Foods, Engelwood Cliffs, N.J.

3. Cerelose, Clinton Corn Processing Co., Clinton, Iowa.

4. Mineral mix provides $(\mathrm{g} / 100 \mathrm{~g}$ of diet): $\mathrm{Mg}, 0,0.005,0.1$, or $0.15 ; \mathrm{K}$ $0.49 ; \mathrm{Na}, 0.17 ; \mathrm{Ca}, 0.528 ; \mathrm{P}, 0.455 ; \mathrm{Cl}, 0.13$. In $\mathrm{ppm}: \mathrm{Mn}, 38.7 ; \mathrm{Cu}$,
5.7; $\mathrm{Al}, 0.20 ; \mathrm{Co}, \mathrm{i} .6 ; \mathrm{Zn}, 13.3 ; \mathrm{F}, 0.016 ; \mathrm{I}, 1.342 ;$ and $\mathrm{Fe}, 83.2$.

5. Sigma Chemical Co., St. Louis, Mo.

6. Water soluble vitamins $(\mathrm{mg} / 100 \mathrm{~g}$ of diet): Thiamin, 2.5 ; riboflavin, 1.0 ; calcium pantothenate, 7.0 ; pyridoxine, 2.2 ; nicotinamide, 5.0 ; folic
acid, 0.4 ; biotin, 0.10 ; PABA, 2.5; inosito1, 25.0; and $\mathrm{B}_{12}, 0.50$.

7. Fat soluble vitamins (Units/100 g of diet): Retinyl palmitate, 1,000; ir radiated ergosterol, 270 I.U. of vitamin $D ;$ DL-alpha-tocopheryl acetate 10.0; and 3 -phytylmenadione (vitamin $K_{1}$ ), $0.1 \mathrm{mg}$.

TABLE 2 A.

BLOOD VALUES IN WEANLING RATS: HEMATOCRIT AND PLASMA CATIONS

CATIONS IN MEQ/LITER (MEAN \pm SEM).

\begin{tabular}{|c|c|c|c|c|c|}
\hline $\begin{array}{c}\begin{array}{l}\text { GROUPS OF RATS } \\
\text { (Number) }\end{array} \\
\end{array}$ & $\begin{array}{l}\text { VENOUS BLOOD } \\
\text { HEMATOCRIT \% }\end{array}$ & MAGNESIUM & CALCIUM & POTASSIUM & SODIUM \\
\hline $\begin{array}{l}\text { A. } 100-\mathrm{Mg}(24) \\
\mathrm{Ad} \mathrm{lib.*}\end{array}$ & $28.4 \pm 0.60^{2}$ & $1.68 \pm 0.03^{2}$ & $5.15 \pm 0.04$ & $5.92 \pm 0.21$ & $136.6 \pm 0.49$ \\
\hline B. $\begin{array}{l}100-\mathrm{Mg}(20) \\
\text { Pair-fed }\end{array}$ & $30.8 \pm 0.78$ & $1.58 \pm 0.02$ & $5.25 \pm 0.06$ & $5.55 \pm 0.13$ & $137.3 \pm 0.56$ \\
\hline C. $\begin{array}{l}\text { loo-Mg (14) } \\
\text { Pair-fed } \\
\text { Strychnine } \\
\text { seizures * }\end{array}$ & $35.0 \pm 0.94^{4}$ & $2.20 \pm 0.09^{5}$ & $6.35 \pm 0.10^{5}$ & $9.31 \pm 0.26^{5}$ & $143.2 \pm 0.59^{5}$ \\
\hline $\begin{array}{ll}\text { D. } & 0-M g(9) \\
\text { No seizure } & \end{array}$ & $33.6 \pm 0.77^{1}$ & $0.31 \pm 0.01^{5}$ & $5.40 \pm 0.08$ & $8.04 \pm 0.30^{5}$ & $134.4 \pm 0.44^{4}$ \\
\hline $\begin{aligned} & \text { E. } 0-M g(6) \\
& \text { Early } \\
& \text { seizures ** }\end{aligned}$ & $37.7 \pm 1.17^{3}$ & $0.38 \pm 0.02^{1}$ & $5.50 \pm 0.12$ & $8.55 \pm 0.29$ & $134.5 \pm 0.69$ \\
\hline F. $\begin{array}{l}\text { O-Mg (11) } \\
\text { Prolonged } \\
\text { seizures } * *\end{array}$ & $46.1 \pm 1.18^{5}$ & $0.76 \pm 0.07^{5}$ & $6.35 \pm 0.15^{5}$ & $9.34 \pm 0.58$ & $141.3 \pm 1.51^{2}$ \\
\hline
\end{tabular}

(*) Compared with Group B, Pair-fed 100-Mg controls, using two-tailed Student's t test.

(**) Compared with Group $D, 0-M g$ rats with no known seizures, using two-tailed Student's t test.

1. $P<0.05 ; 2$. $P<0.025 ; 3 . P<0.01 ; 4$. $P<0.005 ;$ 5. $P<0.001$. 
TABLE 2 B.

BLOOD PLASMA VALUES IN WEANLING RATS: PLASIAA ENZYME ACTIVITY

\begin{tabular}{|c|c|c|c|c|c|}
\hline \multicolumn{6}{|c|}{ UNITS/LITER (MEAN \pm SEM $)$. } \\
\hline $\begin{array}{l}\text { GROUPS OF RATS } \\
\text { (Number) }\end{array}$ & $\begin{array}{l}\text { ALIKALIME } \\
\text { PHOSPHATASE }\end{array}$ & $\overline{\mathrm{SG}} 0 \mathrm{~T}$ & SGPT & $\mathrm{LDH}$ & $\begin{array}{l}\text { CREATINE } \\
\text { KINASE } \\
\end{array}$ \\
\hline 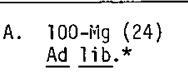 & $1264.2 \pm 69.3^{5}$ & $118.2 \pm 7.4$ & $31.3 \pm 2.7$ & $365.2 \pm 40.8$ & $494.1 \pm 50.8$ \\
\hline 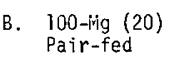 & $907.1 \pm 47.6$ & $101.5 \pm 3.2$ & $27.2 \pm 1.1$ & $303.5 \pm 37.1$ & $384.5 \pm 29.4$ \\
\hline $\begin{array}{l}\text { C. } 100-M g(14) \\
\text { Pair-fed } \\
\text { Strychnine } \\
\text { seizures }\end{array}$ & $1007.0 \pm 99.2$ & $130.5 \pm 6.9^{5}$ & $35.7 \pm 1.3$ & $383.9 \pm 32.4$ & $525.8 \pm 45.3^{2}$ \\
\hline $\begin{array}{l}\text { D. } \begin{array}{l}0-M g(9) \\
\text { No seizures * }\end{array}\end{array}$ & $219.5 \pm 20.6^{5}$ & $164.5 \pm 15.6^{5}$ & $30.7 \pm 1.6$ & $437.5 \pm 110.7$ & $584.8 \pm 150.2$ \\
\hline E. $\begin{array}{l}\text { O-Mg }(6) \\
\text { Early } \\
\text { Seizures** }\end{array}$ & $251.5 \pm 13.2$ & $141.0 \pm 9.6$ & $26.5 \pm 1.6$ & $399.3 \pm 82.3$ & $520.0 \pm 70.7$ \\
\hline F. $\begin{array}{l}\text { 0-i1g (11) } \\
\text { Prolonged } \\
\text { Seizures }\end{array}$ & $294.0 \pm 14.1^{3}$ & $377.3 \pm 58.4^{3}$ & $58.9 \pm 14.3$ & $1448.7 \pm 229.7^{2}$ & $1527.5 \pm 239.5^{5}$ \\
\hline
\end{tabular}

(*) Comparea with Group B, Pair-fed 100-rig controls, using two-tailed Student's $t$ test.

(**) Compared with Group D, O-Mg rats with no known seizures, using two-tailed Student's $t$ test.

1. P<u. vö; 2. $P<0.025 ;$ 3. $P<0.01 ; 4$. $P<0.005 ;$ 5. $P<0.001$.

TABLE 2 C.

BLOOD PLASMA VALUES IN WEANLING RATS: SELECTED ANIONS AND METABOLITES.

\begin{tabular}{|c|c|c|c|c|c|c|c|c|c|}
\hline $\begin{array}{l}\text { GROUPS OF RATS } \\
\text { (Number) }\end{array}$ & $\begin{array}{l}\text { CHLORIDES } \\
\mathrm{mEg} / 1 \text { iter }\end{array}$ & $\begin{array}{l}\text { INORG. PHOS. } \\
\mathrm{mg} / \mathrm{dl}\end{array}$ & $\begin{array}{l}\text { GLUCOSE } \\
\mathrm{mg} / \mathrm{dl}\end{array}$ & $\begin{array}{l}\mathrm{BUN} \\
\mathrm{mg} / \mathrm{dl}\end{array}$ & $\begin{array}{l}\text { CREATININE } \\
\mathrm{mg} / \mathrm{dl}\end{array}$ & $\begin{array}{l}\text { TOTAL PROTEIN } \\
\mathrm{g} / \mathrm{dl}\end{array}$ & $\begin{array}{l}\text { URIC ACID } \\
\mathrm{mg} / \mathrm{dl}\end{array}$ & $\begin{array}{l}\text { IRON } \\
\mu \mathrm{g} / \mathrm{dl}\end{array}$ & $\begin{array}{l}\text { TOT. BILIRUBIN } \\
\mathrm{mg} / \mathrm{d} l^{-}\end{array}$ \\
\hline 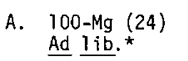 & $102.5 \pm 0.5^{\#}$ & $9.19 \pm 0.14^{5}$ & $179.8 \pm 4.6$ & $18.4 \pm 1.00$ & $0.15 \pm 0.01^{5}$ & $4.56 \pm 0.02^{2}$ & $0.95 \pm 0.08^{3}$ & $260.2 \pm 24.1$ & $0.03 \pm 0.01$ \\
\hline $\begin{array}{l}\text { B. } 100-\mathrm{Mg}(20) \\
\text { Pair-fed }\end{array}$ & $102.8 \pm 0.6$ & $7.90 \pm 0.17$ & $196.3 \pm 30.5^{x}$ & $18.1 \pm 1.26$ & $0.30 \pm 0.03$ & $4.42 \pm 0.04$ & $0.70 \pm 0.04$ & $244.6 \pm 20.7$ & $0.04 \pm 0.01$ \\
\hline C. $\begin{array}{l}100-\mathrm{Mg}(14) \\
\text { Pair-fed } \\
\text { Strychnine } \\
\text { seizures* }\end{array}$ & $104.5 \pm 0.5$ & $10.25 \pm 0.44^{2}$ & $197.4 \pm 17.8^{x}$ & $21.7 \pm 1.04$ & $0.30 \pm 0.03$ & $5.19 \pm 0.06^{5}$ & $1.12 \pm 0.09^{5}$ & $390.4 \pm 40.8^{4}$ & $0.04 \pm 0.01$ \\
\hline $\begin{array}{l}\text { D. } 0-M g(9) \\
\text { No seizures* }\end{array}$ & $105.1 \pm 0.8$ & $8.55 \pm 0.23^{1}$ & $147.1 \pm 3.4$ & $21.5 \pm 2.75$ & $0.37 \pm 0.05$ & $3.81 \pm 0.11^{5}$ & $1.02 \pm 0.07^{5}$ & $359.6 \pm 12.0^{4}$ & $0.10 \pm 0.01^{2}$ \\
\hline 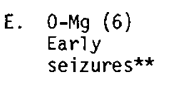 & $102.8 \pm 1.1$ & $7.75 \pm 0.15^{7}$ & $153.8 \pm 5.1$ & $21.6 \pm 5.15$ & $0.43 \pm 0.05$ & $4.03 \pm 0.06$ & $0.85 \pm 0.03$ & $385.0 \pm 18.5$ & $0.13 \pm 0.02$ \\
\hline F. $\begin{array}{l}0-M g(11) \\
\text { Prolonged } \\
\text { seizures ** }\end{array}$ & $105.0 \pm 2.1$ & $11.20 \pm 0.59^{4}$ & $146.0 \pm 5.2$ & $18.2 \pm 0.53$ & $0.43 \pm 0.01$ & $4.52 \pm 0.12^{5}$ & $3.62 \pm 0.38^{5}$ & $458.2 \pm 27.3^{3}$ & $0.12 \pm 0.01$ \\
\hline
\end{tabular}

(*) Compared with Group B, Pair-fed 100-Mg controls, using two-tailed Student's $t$ test.

${ }^{* *}$ ) Compared with Group $D, 0-M g$ rats with no known seizures, using two-tailed Student's $t$ test.

1. $P<0.05 ; 2$. $P<0.025 ; 3 . P<0.01 ; 4$. $P<0.005 ;$ 5. $P<0.001$.

(x) Rats consumed all of restricted ration $1-2 \mathrm{~h}$ before study

(\#) Mean \pm SEM

Copyright $(1) 1978$ International Pediatric Research Foundation, Inc.

Printed in U.S.A. 0031-3998/78/1211-1157\$02.00/0 